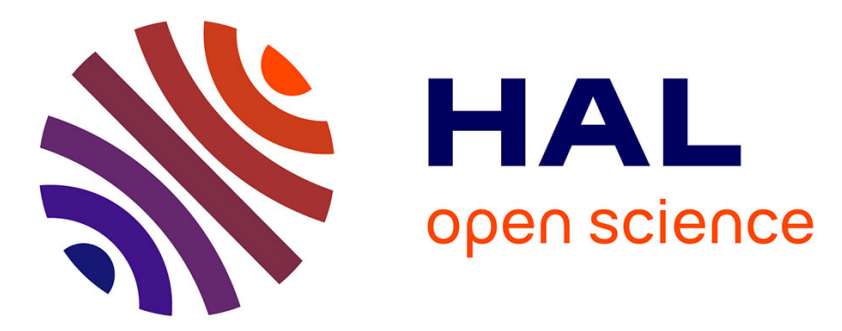

\title{
Between Rome and Constantinople: The Romanness of Byzantine southern Italy (9th-11th centuries)
}

Annick Peters-Custot

\section{To cite this version:}

Annick Peters-Custot. Between Rome and Constantinople: The Romanness of Byzantine southern Italy (9th-11th centuries). W. Pohl, Cl. Gantner, C. Grifoni, M. Pollheimer-Mohaupt. Transformations of Romanness. Early Medieval Regions and Identities, De Gruyter, pp.231 - 240, 2018, Millenium-Studien/Millenium Studies, 10.1515/9783110598384-016 . halshs-03326361

\section{HAL Id: halshs-03326361 https://shs.hal.science/halshs-03326361}

Submitted on 25 Aug 2021

HAL is a multi-disciplinary open access archive for the deposit and dissemination of scientific research documents, whether they are published or not. The documents may come from teaching and research institutions in France or abroad, or from public or private research centers.
L'archive ouverte pluridisciplinaire HAL, est destinée au dépôt et à la diffusion de documents scientifiques de niveau recherche, publiés ou non, émanant des établissements d'enseignement et de recherche français ou étrangers, des laboratoires publics ou privés. 


\section{Corrections : p. 3 and p. 10 (n. 44)}

Annick Peters-Custot

\section{Between Rome and Constantinople: the Romanness of Byzantine southern Italy $\left(9^{\text {th }}-11^{\text {th }}\right.$ centuries)}

Medieval Southern Italy and Sicily hosted the three monotheisms, the two main spheres of Christianity, Roman and Oriental, an Islamic polity, two empires, principalities, and many different kingdoms: the most important political entities and the main communities of the medieval Mediterranean coexisted in a restricted area. It is no wonder that this zone is nowadays considered as a laboratory for the analysis of medieval Mediterranean communities: Norman ethnogenesis, Greek identity and communities, Sicilian 'Mozarabs' and Sicilian Arab-speaking Jews, the concepts of identity and of community. All these themes wove into a complex setting within which there are numerous historiographical novelties: ${ }^{1}$ since 'ethnic' identity seems inappropriate, the legal criterion is now considered essential. Besides, the story of the different cultural religious minorities in the Mediterranean world seems now shaped over all by political constructions, particularly the imperial ideology. $^{2}$

It would be wrong to consider that peoples do not exist for empires: empires often give a historical life to these peoples by giving them names and describing their customs. And the groups that make up the population of an empire are known and recognized by their linguistic, juridical and religious diversities. But all these distinctions are politically neglected, drowned in the imperial ocean, and subordinated to the submission to the emperor. In the medieval Eastern Empire, the so-called 'Byzantine Empire', the douleia, that brings together all the basileus' subjects, implies that these latter are Romans because their emperor is the heir and successor of the ancient Roman emperors. ${ }^{3}$ So the nature of imperial power gives the subjects their political identity: a Roman emperor has Roman subjects - and the imperial population is Roman while still being Georgian, Armenian, Greek or Calabrian.

1 See: Canosa 2009 about the Norman ethnogenesis, Peters-Custot 2009a for the Greek of Southern Italy; Colafemmina 1995 for the Apulian Jews, Bresc/Nef 1998 for the Sicilian 'Mozarabian'; Bresc 2001 for the Sicilian Jews. See also Di Carpegna Falconieri 2012b and Nef 2013 on medieval collective identities, minorities and communities. Di Carpegna Falconieri, for example, concludes his remarkable presentation of the Roman militia in the seventh and eighth centuries fighting the very notion of identity, that is of a stable and closed cultural awareness: the Roman miles hates his Lombard neighbour, certainly knows the Greek language, prays in front of icons that are the same as those found at Constantinople, but his weapons are German ones. It is likely that all the warriors resembled each other more than they certainly would have admitted themselves. About the notion of acculturation, see the online presentation by Peters-Custot, 'De l'usage de l'acculturation' (Peters-Custot 2013b).

2 Nef 2011, 3; Peters-Custot 2009b.

3 Guillou 1967. 
This perception of people in an empire is not a distinctive feature of the Byzantine world. It appears in the Ottonian Empire, ${ }^{4}$ and even in political constructions that claim an imperial ideology without wearing the name: I refer to the Norman kingdom of Sicily. ${ }^{5}$

So, in the logic that we name with a characteristic but perfectly accepted anachronism, 'Byzantine', the concept of Romanness reflects always something political, implying the belonging to a political construction that claims an imperial identity (if not the name of empire) and the inheritance of ancient Rome's emperors. The medieval Eastern Empire, it is well known, demanded a monopoly over this Romanness, a monopoly that, naturally, the western world denied it and which led, in the ninth and tenth centuries, to the blooming of a well-known polemic literature that we will not discuss in this paper. ${ }^{6}$

Medieval Romanness in the Eastern Empire, however, has nothing to do, theoretically, with peoples. In particular, in the case of the two Byzantine provinces in Italy between the ninth and the eleventh centuries, Apulia and Calabria, Romanness and the consciousness of Romanness should be the same: the Greek populations of Byzantine Italy, concentrated over all in southern Calabria, should not be more 'Roman' than the Lombard, Latin-speaking populations of Byzantine Apulia. Yet, this theoretical vision is not to be seen in the documents.

On the one hand, the sources from Constantinople make a clear distinction, based upon cultural criteria, between the inhabitants of the two provinces. For Constantine VII Porphyrogenitus, the Calabrian people is the only 'Roman' one in Italy ${ }^{7}$ and, in the eleventh century, the Byzantine population of Italy is seen as 'mixo-barbarian', a new category made up at Constantinople to indicate the semi-Romans and semi-barbarians on the empire's periphery, which is the mirror of the empire's ever weakening ability to integrate. ${ }^{8}$ Later again, Anna Comnena expresses all the prejudices developed by the Byzantine élites against Italo-Greeks when she introduces John Italos, a pseudo-Byzantine Italian, who, according to her, was not fluent in

\footnotetext{
4 So writes Liutprand, bishop of Cremona, when referring to the western emperor and designating his people: scripsit et de imperio vestro et gente nostra - 'nostrum' nunc dico omnes quae sub vestro imperio est gentem. Liutprand of Cremona, Relatio de legatione, c. 40, ed. Chiesa.

5 See Nef 2011, 145-174; Nef 2012, 236-244; and Nef 2013. The religious and ecclesiastical consequence of the Hauteville imperial ideology, that makes the sovereign the master and chief of his church, is to read in Fodale 1970 and Peters-Custot 2009a, 240-246. The absence, in the Norman Realm of Sicily, of a policy having specifically religious communities as objects, is also a feature of Southern Italy under the Byzantine imperial rule: see Peters-Custot 2013a.

6 See Peters-Custot 2014.

7 Constantine Porphyrogenitus, De administrando imperio, c. 27, ed. Moravcsik, trans. Jenkins, $113-$ 119; and Peters-Custot 2009a, 136-138.

8 About these 'mixo-barbarians', categories developed in the eleventh-century Byzantine Empire, more particularly at Constantinople among the élites, see: Ahrweiler 1976 and, for the presence or the conception of such a category in Byzantine Southern Italy: Peters-Custot 2005 and Peters-Custot 2006.
} 
the language of the true 'Romans', and really poor in the major science of the Byzantine élite, that of rhetoric. ${ }^{9}$

On the other hand, the Apulian and the Calabrian sources do not express feelings of Romanness in the same way.

Byzantine Apulia is, paradoxically, the Empire's Italian province that shows most obviously the administrative criteria for belonging to the Eastern Empire: agents of public administration, above all the Katepano, who sit in the main city of Bari, in the Praitorion; ${ }^{10}$ but also an army, whose military service, from quite early on, was often modified in line with the imperial army in the East; a monetary system that was completely dependent on Constantinople (although Calabria was in the monetary and trade orbit of the Islamic world) and a Byzantine tax system that is well known (the Calabrian sources are silent on that topic). ${ }^{11}$ Constantinople devoted a great deal of attention to Apulia, and much more than to southern Calabria, which was abandoned to be the prey of the Arab attacks from Sicily. In this region, where integration into the Byzantine Oikoumene was an important geostrategic challenge, all the regional Byzantine administrative framework and functions were adapted from the previous Lombard ones. The same individuals or families continued to hold on to local administrative functions, from gastald to tourmarkos, ${ }^{12}$ the law was still Lombard, and the ecclesiastical framework, structured entirely in Latin, was kept under the jurisdiction of ancient Rome.

These smart integrative policies allowed a strong link between the local Lombard élites and the Empire, which contrasts with the autonomy, if not almost complete independence, of Calabria: the latter posed a weaker resistance to the Norman conquest than Apulia. ${ }^{13}$ In this framework, all the marks of 'Romanness', to be seen in the sources that express some 'auto-representation' of the people, are rare and implicit, but evident: on the one hand, the dating of the Latin notarial acta by the reign of the basileis, called Sanctissimi imperatores, is a first sign of political allegiance, even if it does not imply that the authors of the acta consider themselves

9 Anna Komnena, Alexias V, 8 and 9, ed. and trans. Leib, vol. 2, 32-40, for Italos' detailed story and especially ibid. V, 8, 6, ed. and trans. Leib, vol. 2, 35-36, for his lack of skills in Greek language and rhetoric (for a German translation of this extract, see Anna Komnena, Alexias, ed. and trans. Reinsch/ Kambylis, 185-189). Described as an 'Italian' - that is to say, in Byzantine political and administrative terms, as a Latin from Longobardia (the Latin province of Byzantine Italy) - John Italos was not a native Greek-speaking Italian. However, he became one of Psellos' students, and his successor as 'philosophers' consul'. Anna Komnena's prejudices toward Italos are well known. Nevertheless, she remains the main source for his biography. On this original and controversial personality, see Paul Magdalino, 'Deux philosophes italiens face à la xénophobie byzantine: répétition ou évolution d'un schéma?', in: L'Italie et l’Orient. Enjeux, échanges, regards croisés, Internationa' rnnference organized by Alessandra Stazzone and Georges Sideris, Paris, 27-29 march 2014 (for ing).

10 Falkenhausen 1986.

11 Martin 1993, 711-715.

12 Martin 2006.

13 Peters-Custot 2009a, 225-232. 
to be 'Roman'. A similar diplomatic phenomenon can be seen amongst the charters of the Lombard princes. On the other hand, the proud claim of a Byzantine imperial title or function reflects also an administrative integration linked to the symbolic capital for these élites. I have studied the distribution of imperial titles and Byzantine administrative functions to the local Lombard élites through the Latin Apulian acta, and I have been able to illustrate that this distribution was part of policies of integration that had real success: the use of Byzantine dignities persisted much longer among the Lombard people than among the Greeks of Calabria after the Norman conquest. ${ }^{14}$ Again, it could be argued that numerous non-Byzantine sovereigns received Byzantine titles (the so-called dignities) without being considered or considering themselves subjects of the basileus. However, this is not the same case in Byzantine Apulia. Here, titles such as tourmarkoi and protospatharioi were not given to establish diplomatic links, but to maintain the administration of the Italian provinces of a faraway empire.

So the Lombard population of Byzantine Italy, although integrated into the Empire only from the second half of the tenth century onwards, and still exclusively linked to Lombard law and to western culture and religious practices, developed quite quickly the support, albeit only political, of the Eastern Empire and emperor, that meets the notion of 'Romanness' in an imperial context: their cultural features were never being rejected or oppressed, so their political support was sincere, even if concealed. This could be possible only because the western world kept an ideology in which empire was the standard of political construction, as the highest degree of the ideal state.

Regarding the population of Byzantine Calabria, their linguistic 'Greekness', their Byzantine law, their eastern liturgy and ecclesiology, their onomastic 'Byzantine-type' choices put them in the cultural orbit of Eastern Empire. ${ }^{15}$ And yet, the perception the Italo-Greeks had of themselves, as visible through the documentary testimonies, such as hagiographical texts or notarial acta, is not so clear and evident. ${ }^{16}$

On the one hand, the juridical, cultural and religious coherence with the Eastern Roman Empire is never clearly explained and explicit. It never expresses itself in the local documentation, but is deduced from sets of indications, from hints, a posteriori. For example, Byzantine notarial acta offer a glimpse of contemporary church norms, when they display clearly the name of priests' children, even though, as a result of ecclesiastical opposition, this practice becomes less and less visible in the sources. In the juridical field, the use of Byzantine law is never expressed, in so far as the notarial acta never make precise citation of a law before the end of the twelfth century: ${ }^{17}$ Byzantine law can be grasped through the practical evidence, such as those charters that distinguish Byzantine from Lombard law, especially concerning wom-

14 Peters-Custot 2009a; Peters-Custot 2012c.

15 Peters-Custot 2009a, 32-50; Peters-Custot 2012b.

16 Peters-Custot 2006.

17 Peters-Custot 2012a. 
en's rights, which both are theoretically opposed to. But even in this case, the natural acculturation, emerging spontaneously from the frequent contacts between populations inside Byzantine Italy, where the use of Lombard law is tolerated, was a very complex process that gave birth to highly nuanced realities. For example, behind the word theoretron, which indicates the Byzantine matrimonial endowment given to the bride, there is most often, and even for women under Byzantine law, a Lombard Morgengabe also called Quartam partem, since this endowment is fixed as the quarter part of the man's goods. ${ }^{18}$

There is one exception to this silent use of Byzantine law in southern Italy: when the Italo-Greek communities were minorities in a Latin-Lombard landscape. In Byzantine Apulia, in Taranto for example, in the tenth and eleventh centuries, as well as in Salerno, in the Lombard principality, the Greek community is visible through the presence of a 'chorepiskopos' and of a 'judge of the Greeks'. ${ }^{19}$ The Salernitan Latin acta kept at the Abbey of Cava de' Tirreni, demonstrate for the twelfth century a new need for explicit juridical distinction. ${ }^{20}$ This phenomenon affects all the local population groups. They require the notary to express that they are acting secundum legem et consuetudinem gentis nostrae Longobardorum, or secundum legem et consuetudinem Romanorum. The latter is quite ambiguous, as it is used by the members of the Greek community coming from Calabria and Sicily, as well as by those coming from Naples, Amalfi, Atrani, and Gaeta, all Tyrrhenian dukedoms which proudly and constantly claim the use of Roman-Justinian law. Such an ambiguity, that nowadays presents some difficulties of historical interpretation, will emerge again in the twelfth and thirteenth centuries, when references to 'Roman' law will occur in the private notarial acta written down in Southern Italy, either in its Latin-speaking part, or in its Greek-speaking one. ${ }^{21}$

Therefore, the external expression of the cultural, religious and juridical 'Byzantiness' is mostly an implicit one, except when the Greeks became a minority after the Byzantine period.

On the other hand, the members of this Italo-Greek group themselves, and particularly in Calabria, which by this time was wholly Hellenised, claimed a strong support from Byzantine political ideology, and their conception of imperial power is in perfect harmony with Byzantium, which considers the emperor as God's lieutenant on earth: when the great tenth-century Italo-Greek saint Elias Speleotes sees in a dream an imperial procession led by the basileus, he concludes that his end is near since, just as the emperor is Christ on earth, the emperor in his dream is nothing but Christ coming to collect him. ${ }^{22}$ Such complete political integration of Byzantine Italy at this time can be seen also in the notarial acta, where any rebellion is present-

18 Peters-Custot 2009a, 146-150.

19 For Taranto see Martin 1991; for the Greek community of Salerno, Peters-Custot 2009b.

20 Peters-Custot 2009b, 92-95.

21 Peters-Custot 2012a.

22 AA SS Sept. III, 878, 73. 
ed as the equivalent to apostasy, where the rout of the imperial army signifies chaos, and where the penalty clause defines the violation of a juridical act as disloyalty 'against God and the emperor's salvation'. ${ }^{23}$ At the same time, the emperor's agents are sharply criticized, with a disapproval that never affects the basileus himself. Iniquitous and cruel strategoi, and powerful and jealous bishops are the objects of a strong and common disapproval, and even divine retribution. ${ }^{24}$ Thus Italian political support of Byzantine political ideology is a sign of approval of a distant emperor. That is probably why geographical remoteness was not the cause for political distance at all. However, this very same remoteness explains why the Greeks coming from southern Byzantine Italy and moving in other regions of the Eastern Empire felt like strangers, xenoi. ${ }^{25}$ The word, claiming the necessary exteriority of the monk from the secular world, sounds deeply spiritual in the monastic hagiographical literature, but not only there. The xeniteia is truly effective, and the holy monk who dies in Thessaloniki as in a 'foreign country' does not feel at home. ${ }^{26}$ This xeniteia is however true to the original Byzantine type of foreigner. The xenodocheia are exactly built to house, in priority, travellers, 'Roman' pilgrims, who are outside their normal residency and homeland. ${ }^{27}$ So, even with the expression of the feeling of xenos, the Greeks of Southern Italy are complying with the Byzantine standard of xeniteia.

Homeland is the real, true and most deeply rooted base of the Italo-Greeks when travelling abroad or meeting foreigners: they introduce themselves to other people by naming their homeland and the authors of saints' lives always start their holy narratives by defining the heroes' fatherland. This homeland is illuminated forever by their glory. Moreover, leaving everything for God meant precisely going so far as leaving the homeland's soil, according to a sentimental geography that became a hagio-

23 The most meaningful examples can be seen in the Italo-Greek notarial acta. In the acta of the dux Argyros dated 1053, for instance, Basil Chrysogenos, wholed a rebellion against the imperial agents in


no. 5. Besides, the rout of the imperial army means the emergence of chaos and complete disorder,

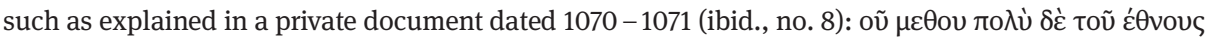

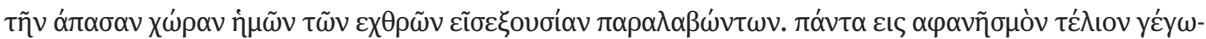

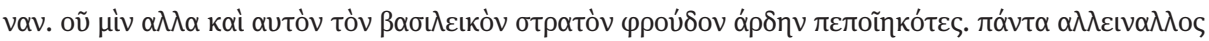

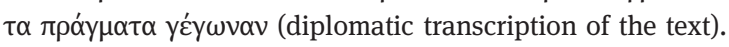

24 See for example the struggle between Saint Elias Speleotes, and an evil priest sustained by an unfair strategos of Calabria: AA SS Sept. III, 853, 14-854, 15.

25 It is, in particular, the case for Saint Elias the Younger, who died, according to the author of his Life, 'in a foreign land', as he stayed at Thessaloniki, after having felt the same feeling of being a stranger (The Life of Saint Elias the Younger, cc. 28, 68, ed. and trans. Rossi-Taibbi, 42-45, 108-111). 26 I have briefly analysed this feeling in Peters-Custot 2006 without being completely aware, at this time, of the fact that it was a widespread feeling in the Byzantine world. Being affectively bound to one's region conceived as the motherland and, at the same time, feeling a stranger, if not an alien, in another part of the Byzantine Empire constituted a normal perception of the membership of an empire in the medieval times.

27 See Kaplan 2014. 
graphical cliché. Linked to this homeland, a genos defines the traveller's identity. ${ }^{28}$ That is why the Italo-Greek traveller, when travelling out of his native Calabria, and even if still in the Byzantine Empire, is a foreigner, as well as people coming from other peripheral areas of this Empire.

In the Italo-Greek sources, the idea of 'Roman', beloved in the Byzantine world, remains rare and evanescent. The Greeks and the Lombards from Byzantine Italy never speak of themselves as 'Romans', except for one case: a testament, written down in the Lombard milieu of Bari, where a Calabrian woman, living under Byzantine law, frees her slave so that he becomes 'free and a Roman citizen' (politès Rhômaiôn). ${ }^{29}$ This case concurs with the juridical claim among minority communities, as developed above. The other main references to 'Roman' in the sense of 'Byzantine' refer to a military context: in the Life of St Elias the Younger, one of the most important Italo-Greek saints of the Byzantine period, Romans are Byzantine soldiers sent to defend the Christians against the Arabs. ${ }^{30}$

So, again, 'Byzantine' individuals from Italy never describe themselves as 'Roman', although 'Romanness' is supposed to be the political foundation for being part of the Eastern Empire. Byzantine Italy is included in a space which confronts two empires that claim to be called 'Roman', a city called 'Rome' and a bishop who yearns for ruling the 'Roman' Church: this unique, specific situation may explain the lexical weakness of Italo-Greek 'Romanness' bound, in the end, to the polysemy of the word 'Roman'. This word signifies too much to be suitably used. ${ }^{31}$

In the Life of St Elias the Younger, already cited, if basileus Leo VI the Wise holds the basileia of the Romans, ${ }^{32}$ St Elias, when coming to Rome, encounters Pope Stephen V, who 'holds the tiller of the Roman Church'. ${ }^{33}$ One detects how the western way of conceiving Romanness spread into Italo-Greek hagiography. This discourse, which claims the monopoly of the use of Romanus for the city of Rome, the popes and sometimes the western emperors, has been most often analysed in its polemic dimension, in the context of struggles between the pope and Constantinople's patriarchate, or of competition between the two emperors, ${ }^{34}$ as disclosed in the letter written down by Anastasius Bibliothecarius for Basileus Basil I in $871 .^{35}$ In fact, the end of the ninth century is a period during which a polemical rhetoric against the Eastern

28 Peters-Custot 2006.

29 Le pergamene di S. Nicola di Bari, no. 46, 11. 42-43, ed. Nitti, 93.

30 The Life of Saint Elias the Younger, cc. 7 and 25, ed. and trans. Rossi-Taibbi, 10-13, 36-39.

31 Peters-Custot 2006.

32 The Life of Saint Elias the Younger, c. 66, ed. and trans. Rossi-Taibbi, 104-107.

33 The Life of Saint Elias the Younger, c. 36, ed. and trans. Rossi-Taibbi, 54-57.

34 See recently: for the eighth century, Gantner 2013a and for the ninth-eleventh centuries, PetersCustot 2014.

35 This letter is included in the Chronicon Salernitanum (Chronicon Salernitanum, c. 107, ed. Westerbergh, 106-121). The huge difference of literary level between this letter and the rest of the Chronicon proves that the author certainly copied it, being unable to write down a text of such a high quality. On this letter see further Peters-Custot 2014. 
Empire developed, especially in Rome, but also elsewhere in parts of western Europe. ${ }^{36}$ This rhetoric emerged again with the rebirth of a Western Empire in $962 .{ }^{37}$ Chris Wickham linked the foundation of such an aggressive rhetoric made up of negative topoi with the decline of central Carolingian authority that led to the weakening of a centralized court culture and to the increasing inability of western powers to understand the complexity of the eastern world. ${ }^{38}$

Now, there can be dispassionate discourse in a peaceful, non-antagonistic context, which occurs less frequently in the sources: yet, in this western discourse, 'Romanness' has been seized and carried off by Rome, and by all those who are living there, including those who are bishops, or those who, having been crowned emperors there, had a duty to defend the city. ${ }^{39}$ The imperial dignity of the Eastern Empire and its sovereign are not diminished or weakened: the basileus is 'Constantinople's emperor', and the 'Byzantine' people are Greci, without that word reducing the Byzantine Romanness to an ethnic dimension. ${ }^{40}$ This term seems to have been used because it was convenient; it was the administrative language and, perhaps, the main liturgical language of the Eastern Empire. ${ }^{41}$

36 See, for example, the negative perception in the Liber Pontificalis Ecclesiae Ravennatis, ed. Mauskopf Deliyannis, as well as in Erchempert, Historia Langobadorum Beneventanorum, ed. Pertz/Waitz. 37 About these polemical discourses, see Rapp 2008. While the first mission of Liutprand of Cremona to Constantinople under the reign of Constantine Porphyrogenitus, before 962, went really well and Liutprand returned enthusiastic, if not dazzled - the second one, to visit Nikephoros II Phokas, after 962, was, according to Liutprand's record, a disaster. The Italian bishop used in the Relatio de legatione Constantinopolitana all the current stereotypes against the Greek (awful food, very bad Grecorum vinum and disgusting garum, physical ugliness and moral monstrosity, cowardice associated to lowness, etc.) to prove his reconstruction of reality.

38 Wickham 1998, 254.

39 As I demonstrated in Peters-Custot 2014. The 'Romanness' of the western emperor, who only merits the title of 'Roman' because he was crowned by the pope in Rome (as explained by Anastasius Bibliothecarius in his letter written in the name of the western emperor and addressed to basileus Basil I, dated 871), implies a duty: to defend the city of Rome when threatened. As soon as a few years later, pope John VIII again expressed this imperial 'Romanness' and the implied duties when explaining to emperor Charles the Bald that, once having received the imperial unction, he was begot by the 'religious womb of Virgin Mary', as a second birth, a spiritual one. This privilege goes with the duty of defending the pope against the contemporary Arab threat: see Peters-Custot 2012d.

40 Chronicon Salernitanum, ed. Westerbergh, 3, 1. 19; and above all ibid. c. 11, ed. Westerbergh, 17, 11. 14-19: the regnum Romanum is the regnum Constantinopolitanum. Constantinople receives the name of urbs Regia in the extract of the Chronicon Salernitanum that mentions the death of Basil I., 'pious August' (ibid. c. 129, ed. Westerbergh, 142, 1. 14 ff.). Anastasius' letter, dated 871, addressed Basil, gloriosissimus et piissimus imperator Nove Rome (ibid., c. 107, ed. Westerbergh, 107, 1. 30).

41 See Peters-Custot 2014. Such a quite neutral, if not positive valuation of the Eastern Empire is to be seen in the Chronicon Salernitanum, as well as in Liutprand of Cremona's record of his first ambassadorship in Constantinople. Even in the 871 letter, the 'Greekness' is associated to the high literary production: for an erudite man like Anastasius Bibliothecarius, it is still an evidence. 
This Roman monopoly upon Romanness, which relied on another definition of Romanness bound to the papacy and the city of Rome, does not seem to harm the Italian Byzantine people and their conception of political identity, which is less a vision of a state than a representation of a power. What seems visible is the fact that the most common written use in the Latin sources of Italy had spread in the ItaloGreek sources, from the end of the tenth century onwards. In the end, the ItaloGreek acta or hagiographies use the word Romanos for Rome, its inhabitants, its army, its pope, precisely in the way the Latin sources do; for all regarding the Eastern Empire, the Latin sources use Grecus while, on the contrary, the Italo-Greek documentation prefers Romanos, with an external and rare rhetoric fidelity to the Eastern Empire's ideology.

The closeness of the city of Rome is certainly one of the the elements that explain how quickly Latin rhetoric about Romanness had been introduced and integrated into the sources written in Byzantine Italy that spoke about old Rome and its popes: the holy Italo-Greek monks, for example, zealously went to Rome in order to perform their devotion to the holy apostles, or for political reasons. There they had one of their most important monastic, aristocratic if not imperial networks ${ }^{42}$ under the Ottonian emperors, while Constantinople always remained a dreamed-of city that none of them ever managed to reach, neither alive nor dead. ${ }^{43}$

Nevertheless, this geographical proximity cannot explain every single aspect of this 'Roman' influence. The end of the tenth century, a period when Italo-Greek surviving sources were written fully under the influence of the vision of 'Romanness' as

42 Nilos the Younger's life certainly represents the most valuable example of such a strong and powerful link between a famous and greatly appreciated Italo-Greek monk and the city of Rome and its élites at the end of the tenth century. This saint is connected either to the Lombard Princes of Capua or to the western emperor, who he met and advised, especially during the case of John Philagathos (Nilos the Younger' Life, ed. Giovanelli 89). Even the Latin hagiography of saint Adalbert of Prague, composed shortly after the facts, gives an echo to Nilos' precious network, especially in Rome's monastic milieu. The young Adalbert, being disappointed by the monks' life at Montecassino and in search of a more rigorous ascetic life, came to see the wise Greek hermit (in fact, living with disciples) who had been recommended to him, to request the permission to spend time with him, as an initiation to the true monastic life. Nilos was reluctant: being the host of Montecassino, and economically dependent upon the abbey, he would not have liked that this case would lead him into a delicate situation. Therefore, he recommended the young aristocrat to join the monastery of Saint-Alexios on the Aventine in Rome, adding that Adalbert should present himself to the abbot as having been sent by Nilos (See Sancti Adalberti episcopi Pragensis et martyris Vita 78, c. 15, ed. Karwasinska). About the monastery of Saint-Alexios: Hamilton 1961 and Hamilton 1965. In addition to Nilos' specific case, let us mention Saint Sabas, who was told to be assisted for his death in Rome by the Empress Theophano herself (Cozza-Luzzi 1893). Sabas' subscription is to be identified with that, in Greek, of a monk Sabas, with his disciple Kosmas, under a Latine notarial document written down in 986 near

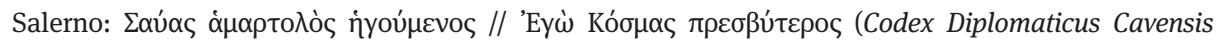
no. 382, ed. Morcaldi et al., 233-234) For the identification, see Da Costa-Louillet 1959-1960, 137, and Borsari 1963, 73. See further Peters-Custot 2009a, 141.

43 For this symptomatic fact, see Peters-Custot 2009a, 141 and n. 281. 
developed in the papal and German entourage, was also the very moment when all the Greeks coming from Calabria and Sicily largely expanded and spread in the Latin areas of the peninsula: Taranto, Salerno, Naples, all the Latium and over all Rome. ${ }^{44}$ No satisfactory reason has ever been given for this quite important migratory phenomenon, which occurred precisely in the 970s and 980s. One can wonder if, after all, Ottonian Rome was not enjoying new powers of attraction bound to the revival of an imperial ideology promoted by the Ottonian authority that intended to make Rome the imperial capital again, while remaining under Byzantine influence, above all after Otto II's wedding to Theophano in 972. At the same time, the papacy developed an insistent rhetoric around Saint Peter's succession, that certainly promoted - or followed - these pious pilgrimages the Italo-Greek people made to Rome.

Renewed imperial presence, combined with papal dynamism revitalized ancient Rome; beyond the controversies, those who represented New Rome were welcomed in the ancient one as the Eastern Empire's delegates. It helped that the emergence of a peripheral version of 'Romanness', between Rome and Constantinople, affected the Italo-Greeks’ self-perception.

44 About the Greeks of Naples, see Martin 2005 and Granier 2008. About those of Salerno, see Peters-Custot 2009b. For the Latium, let us mention the famous monastery of S. Maria di Grottaferrata, near Rome, founded by Saint Nilos the Younger, and also the little monastery of Pontecorvo, and his regula attica (Nicosia 1977, 121): hanc regulam quod dicitur Atticam in Latinam convertere voluerit, maledictus et excommunicatus fiat a Deo patre omnipotente, etc. 